\title{
Melatonin protects rat thymus against oxidative stress caused by exposure to microwaves and modulates proliferation/apoptosis of thymocytes
}

\author{
Dusan Sokolovic ${ }^{1}$, Branka Djordjevic ${ }^{1}$, Gordana Kocic ${ }^{1}$, Andrej Veljkovic ${ }^{1}$, Milena Marinkovic ${ }^{1}$, \\ Jelena Basic ${ }^{1}$, Tatjana Jevtovic-Stoimenov ${ }^{1}$, Zoran Stanojkovic ${ }^{2}$, Danka M. Sokolovic ${ }^{2}$, Voja \\ Pavlovic $^{3}$, Boris Djindjic ${ }^{4}$ and Dejan Krstic ${ }^{5}$ \\ ${ }^{1}$ Department of Biochemistry, Faculty of Medicine, University of Nis, bul. Dr. Zorana Djindjica 81, 18000 Nis, Serbia \\ ${ }^{2}$ Institute for Blood Transfusion in Nis, bul. Dr. Zorana Djindjica 48, 18000 Nis, Serbia \\ ${ }^{3}$ Institute of Physiology, Faculty of Medicine, University of Nis, bul. Dr. Zorana Djindjica 81, 18000 Nis, Serbia \\ ${ }^{4}$ Institute of Pathophysiology, Faculty of Medicine, University of Nis, bul. Dr. Zorana Djindjica 81, 18000 Nis, Serbia \\ ${ }^{5}$ Faculty of Occupational Safety, University of Nis, Čarnojevića 10a, 18000 Nis, Serbia
}

\begin{abstract}
The aim of the study was to evaluate the effect of melatonin on oxidative stress, DNA fragmentation, apoptsis and proliferation in thymus tissue of rats exposed to microwaves. Wistar rats were divided in four groups: I - treated with saline; II - treated with melatonin; III - microwaves exposed; IV - microwaves exposed and melatonin treated. Melatonin ( $2 \mathrm{mg} / \mathrm{kg}$ i.p. $)$ was administered daily. Animals were sacrificed after 20, 40 and 60 days. A significant increase in malondialdehyde and carbonyl group content, as well as decrease in catalase and increase in xanthine oxidase activity were registered under microwave exposure. Melatonin prevented the increase in malondialdehyde and carbonyl group content, and reversed the effect on catalase and xanthine oxidase activity. Both, alkaline and acid DNase activity were increased due to microwave exposure. Furthermore, microwaves caused increase in apoptosis rate (detected using Annexin V-FITC/PI kit) and reduced proliferative capacity of thymocytes (induced by ConA). However, melatonin caused decrease in alkaline and acid DNase activity, decrease in apoptotic rate and increase in proliferation rate of thymocytes. Melatonin exerts protective effects on rat thymocytes by modulating processes of apoptosis and proliferation, and causes decrease in DNA fragmentation and oxidative stress intensity under exposure to microwaves.
\end{abstract}

Key words: Melatonin — Microwaves — Thymus — Oxidative stress — Apoptosis

\section{Introduction}

Use of appliances with sources of microwave (MW) radiation such as TV sets, mobile phones, PC monitors etc. has been, for several decades, an integral part of everyday modern life. International Agency for Research on Cancer (IARC) has recently classified radio frequent- electromagnetic fields (RF-EMFs) as a "possible human carcinogen" (Class 2B)

Correspondence to: Dusan Sokolovic, Department of Biochemistry, Faculty of Medicine, University of Nis, bul. Dr. Zorana Djindjica 81, 18000 Nis, Serbia

E-mail: soko@medfak.ni.ac.rs
(Baan et al. 2011). Electromagnetic fields effects in a wide frequency range from electromagnetic fields to MW have been considered in the frames of the same physical models (Matronchik et al. 1996; Chiabrera et al. 2000; Panagopoulos et al. 2002; Matronchik and Belyaev 2008). It has been known for long time that weak electromagnetic fields and non-thermal MW result to similar effects with significant overplaying of molecular biological pathways for their appearance (Adey 1981; Blank and Goodman 2009; Davanipour and Sobel 2009). Peak electromagnetic fields at the front sides of 5 commercial GSM phones were assessed and a maximum of $22.4 \mu \mathrm{T}$ was reported (Perentos et al. 2008). Electromagnetic fields of about 50-500 nT were shown to 
produce biological effects (St-Pierre et al. 2008). In past few years we are faced with growing public concerns about the effects of chronic exposure to microwave radiation ( 0.3 to $300 \mathrm{GHz}$ ), especially when it comes to it's potentially harmful effect on the immune system.

Immune system plays a crucial role in body defense system and even smallest change of its functionality can lead to cancer or autoimmunity. Thymus is a central organ of the immune system and it undergoes, with time, a complex remodeling through series of compensatory mechanisms, such as slight reduction of mitoses associated with an increased number of apoptosis among different cell populations in a setting of progressive involution (Quaglino et al. 1998). Thymus plays an important role in the immune system development (Matsui et al. 2011) which can be modulated by numerous environmental factors, including MWs (Quaglino et al. 2000). Since the mobile phone is often carried on the neck strap (usually by children), it is therefore in close contact with chest and underneath laying organs including thymus. MWs from high power electric lines, TV towers and mobile phone base stations has already been linked to cancer, especially childhood leukemia and T cell non Hodgin lymphoma (Draper et al. 2005; Lowenthal et al. 2007; Myung et al. 2009). However, some studies showed opposite results regarding this matter (Merzenich et al. 2008; Cooke et al. 2010).

Oxidative stress has been implicated in thymus disorders (Yan et al. 2008). Free radicals, commonly known as reactive oxygen species (ROS), are able to induce cell injury. On the other hand, antioxidative enzymes such as superoxide dismutase (SOD), catalase (CAT) and glutathione peroxidase $(\mathrm{GPx})$ protect the cell from oxidative stress-induced injury. SOD converts $\mathrm{O}_{2}{ }^{--}$into $\mathrm{H}_{2} \mathrm{O}_{2}$, CAT detoxifies $\mathrm{H}_{2} \mathrm{O}_{2}$ and GPx catalyses the breakdown of $\mathrm{H}_{2} \mathrm{O}_{2}$ and lipid hydroperoxides to non-toxic products. Xanthine oxidase (XO), however, is traditionaly considered to be pro-oxidative enzyme which plays an important role in the purines catabolism. Increased XO activity causes increase in production of ROS molecules and therefore cell injury.

Series of studies demonstrated the change in oxidative stress intensity and in antioxidative enzyme activities in various organs after MW exposure (Irmak et al. 2002; Ilhan et al. 2004; Oktem et al. 2005; Meral et al. 2007; Ozguner et al. 2005a,b; Sokolovic et al. 2008). It was reported recently that exposure to electromagnetic fields causes an increase in oxidative stress intensity in thymus tissue of rats as well (Aydin and Akar 2011). MWs cause disbalans in cell defence mechanisms by changing the level of ROS and antioxidant enzyme activity (Belyaev 2010; Georgiou 2010). Lipid peroxidation and oxidative modification of protein molecules are the most important mechanisms of oxidative damage in tissues. Chemical reaction between biomoleculs (proteins,
DNA and phospholipids) and peroxidation secondary products (malondialdehyde, MDA) causes covalent modification of those biomolecules and leads to consequent cell membrane injury and intracellular macromolecules alteration (Mukai and Goldstein 1976). Microwave-induced inhibition of DNA damage repair in different cell types including lymphocytes and stem cells was linked carcinogenesis (Belyaev et al. 2010). The exposure to non-thermal microwave electromagnetic fields generated by mobile phones also affects the expression of many proteins. This effect on transcription and protein stability is mediated by ERK cascade (Friedman et al. 2007).

It is indicated that MWs cause time and dose-dependent cytogenetic damage in human lymphocytes assessed trough micronuclei count (Zotti-Martelli et al. 2000). Furthermore, an increased apoptosis rate in thymus tissue exposed to MWs was also reported (Quaglino et al. 2000). Yet, no changes in apoptosis rate of T lymphocytes exposed to MWs were reported as well (Belyaev et al. 2005).

In addition to this, Cleary et al. (1996) observed a significant reduction in proliferation of T cells exposed to MWs. However, no changes have also been reported regarding T cell proliferation under MW exposure (Huang et al. 2008). Therefore, literature data still remain inconclusive. However, comparison between different studies should be done with care because of different physical and biological variable that should be taken into account (Belyaev 2010).

Melatonin (N-acetyl-5-methoxytryptamine) is neurohormon primarly synthetised and released from pineal gland. In human body, it binds two subtypes of melatonin membrane receptors - MT1 and MT2 (von Gall et al. 2002) and orphan nuclear retinoid receptors of the ROR/RZR subfamily (Smirnov 2001). Melatonin receptor mRNA is expressed in all lymphocyte subpopulations studied from the rat thymus (Pozo et al. 1997).

Melatonin is an immunostimulant (Baydas et al. 2002) and a powerfull antioxidant. It neutralizes directly a number of free radicals, such as superoxside anion, hydrogen peroxide, hydroxyl radical, singlet oxygen, peroxinitite anion, nitric oxide and hypochlorous acid (Reiter et al. 2000). Melatonin shows potential to neutralize hydroxyl radicals in even higher rates than reduced glutathione (GSH) (Poeggeler et al. 1993). Melatonin also stimulates various antioxidant enzymes, such as SOD, GPx and CAT, either by increasing their activity or by stimulating mRNA synthesis (Antolín et al. 1996; Reiter et al. 2000). It is also proved that melatonin prevents oxidative injury of DNA molecules (Jou et al. 2007) and inhibits apoptosis in immune cells (Sainz et al. 2003).

The aim of the present study was to evaluate the effect of melatonin on (1) oxidative stress parametars (such as MDA, protein carbonyls formation, CAT and XO activity) and DNA fragmentation (alkaline and acid DNase activity) in 
thymus tissue of rats after 20, 40 and 60 days long exposure to MWs, as well as on (2) apoptosis and (3) proliferation rate of tymocytes.

\section{Matherials and Methods}

\section{Chemicals}

Reagents were of the highest commercial grade available. Chemicals used for the purpose of this experiment were of analytical grade. Drug solutions were prepared on the day of experiment.

Culture medium (CM) was prepared using RPMI 1640 (Sigma, St Louis, Mo., USA), in accordance with the manufacturer instructions. CM contained $25 \mathrm{mM}$ HEPES, $2 \mathrm{mM}$ glutamine, penicillin $(100 \mathrm{U} / \mathrm{ml})$, streptomycin $(100 \mu \mathrm{g} / \mathrm{ml})$, and $10 \%$ fetal calf serum (FCS).

Concanavalin A (Con A) was purchased from Sigma (Munich, Germany). Con A was dissolved in CM at concentration of $5 \mu \mathrm{g} / \mathrm{ml}$. Anti-proliferating cell nuclear antigen (Anti-PCNA) and anti-rat monoclonal antibodies were purchased from Immunotech (Marseille, France). Annexin V-FITC/Propidium iodide (PI) apoptosis detection kit was purchased from Immunotech (Marseille, France).

\section{Animal model}

Animals used for the procedure were treated in strict accordance with the NIH Guide for Care and Use of Laboratory Animals (1985).

Experiments were performed on 84 adult Wistar albino rats (male, 6-8 weeks old, 150-180 g), bred in the Vivarium of the Biomedical Research Institute, at Medical faculty, Nis, under conventional laboratory conditions. Control and experimental group animals were collectively housed in plastic cages $30 \times 40 \times 40 \mathrm{~cm}(\mathrm{w} \times \mathrm{l} \times \mathrm{h})$ and had ad libitum access to standard laboratory food and water. The housing room was maintained at $24^{\circ} \mathrm{C}$ with $42 \pm 5 \%$ relative humidity and had 12/12-h light/dark cycle (exposure to light from 06:00 a.m. to $06: 00$ p.m.).

All experiments on animals had been approved by the Animal Ethics Board of the Medical Faculty in Nis and were performed according to these guidelines.

\section{Experimental design}

Animals were divided in 4 experimental groups with 21 animals in each group: group I (control) - rats treated with $0.9 \%$ saline, group II (Mel) - rats treated with melatonin ( $2 \mathrm{mg} / \mathrm{kg}$ body weight, i.p.), group III (MWs) - MW exposed rats, group IV (MWs + Mel) - MW exposed rats treated with melatonin ( $2 \mathrm{mg} / \mathrm{kg}$ body weight, i.p.)
Animals in all experimental groups (groups III and IV) were exposed to microwave radiation for 4 hours every day and then moved to rooms with no sources of electromagnetic field. During exposition, the cages with animals were placed on absorbing material made of rubber with wooden isolation surface, with no electroconductors or metal objects nearby. Chronic exposure to microwave radiation lasted for 60 days.

Melatonin was administered intraperitoneally (i.p.) every morning at 08.00 a.m., at a single dose of $2 \mathrm{mg} / \mathrm{kg}$ body weight as proposed by Drago et al. (2001). In control rats, isotonic saline solution (equal to the volume of melatonin) was given intraperitoneally everyday during the follow up. Melatonin used for the purpose of this experiment, was of pro analysi purity (ICN Galenika, Belgrade).

Seven animals from each group were sacrificed after 20, 40 and 60 days. Rats were anesthetized by ketamine $\mathrm{HCl}$ (50 mg/kg, i.p.). Before sacrificing thymus was surgically removed from the chest cavity.

After the surgical removal, each thymus was divided in two halves which were later used either for biochemical analysis or for proliferation and apoptosis assay.

\section{Microwave exposure}

Animals were exposed to MWs for 20, 40 and 60 days (4 h/ day during light period). MWs were produced by a mobile test phone (model NOKIA 3110; Nokia Mobile Phones Ltd.) connected to a Communication Test Set PCDK with PC and appropriate software module. The mobile phone was placed in a special protective compartment made of plastic with the antenna positioned downwards. During MW exposure seven rats were able to move freely in a pure (i.e. lacking any metallic fittings) plastic cage. MW exposure was performed in the same room where all animals were housed. The two mobile test phones and PC module were situated at the wooden desk with rubber surface. The desk was placed at distant part of the room, 5 meters from housed rats. Every four hours during the light period, two cages (MWs and MWs + Mel group) were transfered to the desk. Moble test phone, as a source of MW radiation, was put in each cage. Mobile phone was put in small perforated polycarbonated box in the center of the cage in order to prevent damage that could be caused by rats. Two false mobile phones (turned off) were put in the control and Mel group cages in the same time. After four hours of MWs exposure, the same procedure was applied to the next two cages of investigated groups.

An electromagnetic continuous wave near-field signal for 2G-GSM (Global System for Mobile communication) at $900 \mathrm{MHz}$ was used for the purpose of this experiment. Mobile phone has been operating in test mode controlled by PC (TX mode) during the exposition (transmition mode, TX power level 5, Operation mode - Burst, TX data 
type - Cont 0, Cont Mode Channel - 60, $902 \mathrm{MHz}$, AGC Absolute value - 512, AGC $85 \mathrm{~dB}$ ). Cage floor surface was divided in 9 quadrants, and electromagnetic field parameters were measured in each compartment several times during experimental exposure.

Electrical field intensity was estimated to be in the range from $\mathrm{E}=9.88$ to $18.356 \mathrm{~V} / \mathrm{m}$ and magnetic flux density from $\mathrm{B}=4.68$ to $8.69 \mu \mathrm{T}$ (Aaronia Spectran HF6080 EM field meter). Electrical field parameters in cages of sham-exposed animals were $\mathrm{E}=0.3-0.7 \mathrm{~V}$ and $\mathrm{B}=0.18-0.35 \mu \mathrm{T}$, respectively. The whole-body specific energy absorption (SAR) rate in irradiated animals was estimated to $0.043-0.135 \mathrm{~W} / \mathrm{kg}$ using data for a rotating ellipsoidal rat model.

\section{Preparation of thymocytes; detection of proliferation and apoptosis}

Thymocytes were isolated from the first half of extirpated thymus tissue in accordance with methods previously described by Vermes et al. (1995) and Koopman et al. (1994). In brief, after the surgical removal each thymus was placed in cold CM containing 10\% FCS. Thymocytes were released from the thymus tissue by sliding the tissue along a steel-mesh. Cell suspensions were filtered through a sterile nylon-filter in order to remove stroma and afterwards two times washed with cold CM containing $10 \%$ FCS. Thymocytes were counted and adjusted to a density of $1 \times 10^{7}$ cells $/ \mathrm{ml}$. Cells were cultured in 96-well flat-bottom plates (Sarsedt, Newton, USA), containing $100 \mu \mathrm{l}$ of cell suspension $\left(1 \times 10^{6}\right.$ cells $)$ in each well. All cultures were done in triplicates. Thymocytes were cultured for $72 \mathrm{~h}$ in the incubator (Assab, Sweden) at $37^{\circ} \mathrm{C}$ in an atmoshere containing $95 \%$ oxygen and $5 \%$ carbon dioxide. In addition, thymocytes used for proliferative activity evaluation, were treated with optimal concentration $(5 \mu \mathrm{l} / \mathrm{ml})$ of ConA.

\section{Proliferation assay}

Flow cytometric analysis was used in order to measure lymphocyte proliferation. We measured expression of proliferating cell nuclear antigen (PCNA), an auxiliary cyclin protein necessary for DNA polymerase activity, maximally expressed in mid S-phase as previously proposed by Kühn et al. (1995). Proliferative activity was evaluated after $72 \mathrm{~h}$ of incubation, using anti-PCNA monoclonal antibody. In brief, thymocytes were collected at the end of the culture period, and washed twice in PBS containing 5\% FCS. Afterwards, the cells were fixed in $70 \%$ methanol, for $30 \mathrm{~min}$, at $-20^{\circ} \mathrm{C}$ and then washed again two times with PBS containing $5 \%$ FCS in order to remove methanol. The cells were than incubated in the dark for $1 \mathrm{~h}$ at room temperature, with anti-PCNA monoclonal antibody containing solution (5 $\mu \mathrm{g} / \mathrm{ml})$. After incubation, cells were washed twice and than incubated again with PE-conjugated anti-rat IgG monoclonal antibody containing solutions 45 minutes at room temperature. Non-specific binding was monitored and detected in control cells which were incubated with the secondary antibody (PE-conjugated anti-rat $\operatorname{IgG}$ ) alone. Labeled cells were fixed in $4 \%$ formalin and analyzed (5000 analyzed cells/per sample) using flow cytometer (Coulter XL-MCL, Krefeld, Germany).

\section{Detection of apoptosis}

Annexien V-FITC/PI apoptosis detection kit (Immunotech, Marseille, France) was used for apoptosis estimation as previously proposed by Koopman et al. (1994). The staining was made in strict accordance with the producer's manual. Five thousand cells per sample were analyzed using an Epics XL flow cytometer (Coulter, Krefeld, Germany). Thymocytes that were stained positive for Annexin V-FITC and negative for PI were considered to be in early stage of apoptosis, additionally cells that stained positive for both Annexin V-FITC and PI were considered to be in the late stage of apoptosis. Cells that are stained negative for both Annexin V-FITC and PI were considered to be alive and well, whereas only PI positive cells were considered to be necrotic (Koopman et al. 1994; Vermes et al. 1995).

\section{Tissue sampling}

The second half of the extirpated thymus tissue was prepared as $10 \%$ homogenates. In order to assess oxidative stress parameters and DNA fragmentation, thymus tissue was cut in small pieces and homogenized in ice-cold water using homogenizer (IKA Works de Brasil Ltda Taquara, RJ 22713-00). Homogenates (10\% w/v) were centrifuged at 1500 $\times g$ for $10 \mathrm{~min}$ at $4^{\circ} \mathrm{C}$.

\section{Biochemical analysis}

\section{Determination of $M D A$}

MDA in the thymus tissue was spectrophotometrically determined, based on the chemical reaction between thiobarbituric (TBA) acid and MDA as described by Ohkawa et al. (1979). Homogenate absorption was read at $532 \mathrm{~nm}$. MDA (lipid peroxidation end product) concentration was expressed as nmol per mg of protein, using the MDA molecular absorbance coefficient $\left(1.56 \times 10^{-5} \mathrm{~mol} / \mathrm{cm}\right)$.

\section{Determination of protein oxidation}

Carbonyl group content, used as a quantification of oxidative modified proteins, was determined spectrophotometrically (Levine et al. 1994) using 2.4 dinitrophenylhydrazine (DPNH), a traditional carbonyl reagent. Reactive carbonyl 
derivatives were calculated by using dinitrophenylhydrazine (DPNH) molar extinction coefficient at $370 \mathrm{~nm}\left(22 \times 10^{3}\right.$ $1 / \mathrm{mol} / \mathrm{cm}$ ) and expressed as $\mu \mathrm{mol} / \mathrm{g}$ of protein.

\section{Determination of CAT activity}

Catalase activity was measured spectrophotometrically at $405 \mathrm{~nm}$ as described by Góth (1991). According to this method serum or homogenate was incubated in $\mathrm{H}_{2} \mathrm{O}_{2}$ substrate and the enzymatic reaction was stopped by adding ammonium molybdate. Activity was expressed as micromoles per $\mathrm{mg}(\mu \mathrm{mol} / \mathrm{mg})$ protein.

\section{Determination of XO activity}

Xanthine oxidase activity in thymus homogenate was estimated by the amount of uric acid produced for fixed time interval. In brief, reaction mixture containing $0.1 \mathrm{ml}$ thymus homogenate and $0.1 \mathrm{M}$ Tris/ $\mathrm{HCl}$ buffer, $\mathrm{pH} 7.4$, in a final volume of $2.5 \mathrm{ml}$ was pre-incubated for $15 \mathrm{~min}$ at $37^{\circ} \mathrm{C}$. The reaction was started by adding of $0.5 \mathrm{ml}$ of $0.6 \mathrm{mM}$ xanthine. The oxygen-dependent $\mathrm{XO}$ activity was estimated by the increase of the uric acid content as a result of incubation of this reaction mixture for $30 \mathrm{~min}$ at $37^{\circ} \mathrm{C}$. The uric acid content was calculated by the increase in absorbency at $293 \mathrm{~nm}$ against blank, which was run parallel with the reaction mixture without xanthine. Molar extinction coefficient of $7.6 \times 10^{-3}$ $\mathrm{mol} / \mathrm{cm}$ was used for this purpose (Hashimoto 1974). XO activity was also expressed as $\mathrm{U} / \mathrm{mg}$ tissue protein in thymus homogenate.

\section{Determination of alkaline-DNase I and acid-DNase II activity}

Alkaline and acid DNase activity were determined as described by Bartholeyns et al. (1975). According to this method, DNA was used as substrate. Alkaline DNase activity was determined at optimum $\mathrm{pH} 7.4$ using Tris- $\mathrm{HCl}$ buffer, with the addition of $\mathrm{Mg}^{2+}$ ions as activator and the acid DNase activity, using acetate buffer at optimum pH 5.0.

\section{Determination of proteins}

Protein content in thymus was determined according to Lowry's method (Lowry et al. 1951), using bovine serum albumin as standard.

\section{Statistical analysis}

Results were presented as means \pm SD. Data were analyzed using the one way ANOVA, preformed by means of commercially available statistics software package (SPSS Statistics for Windows, v. 20.0.0, IBM, New York, USA). Statistical significance was set to $p<0.05$.

\section{Results}

MDA levels in thymus tissue of rats exposed to MWs were significantly higher in comparison to control group after 20 days, 40 days and 60 days since the start of the experiment $(p<0.001)$. Reduction of lipid peroxidation was found in thymus tissue of animals both irradiated and treated with melatonin in comparison to animals that were irradiated but did not receive melatonin premedication, after 20 days $(p<0.05)$, 40 days $(p<0.001)$ and 60 days $(p<0.001)$ (Fig. 1$)$.

Protein carbonyls content in the thymus tissue of rats exposed to MWs was significantly higher when compared to controls after 20, 40 and 60 days $(p<0.001)$ of exposure. Melatonin administration to MWs exposed rats in the experiment which lasted 60 days (MWs + Mel group) caused significant decrease in protein carbonyls content $(p<0.001)$ when compared to MWs group (Fig. 2).

Catalase activity was found to be significantly lower in thymus tissue of rats exposed to MWs in comparison to controls after 20 days, 40 days and 60 days $(p<0.001)$ of experiment. Melatonin administartion caused a statistically significant increase in CAT activity in experiments that lasted for 20, 40 and 60 days $(p<0.001)$ (Fig. 3).

As shown in Fig. 4, exposure to mobile phone induced a significant increase in thymus tissue XO activity after 20, 40 and 60 days $(p<0.001)$ of experiment when compared to control. The increase in XO activity was successfully prevented by melatonin application after $20(p<0.01), 40$ and 60 days $(p<0.001)$ when compared to MWs group (Fig. 4).

Alkaline-DNase activity was found to be increased in thymus tissue of rats exposed to MWs in comparison to controls after 20 days, 40 days and 60 days $(p<0.001)$ of experiment (Fig. 5). Melatonin administration led to sig-

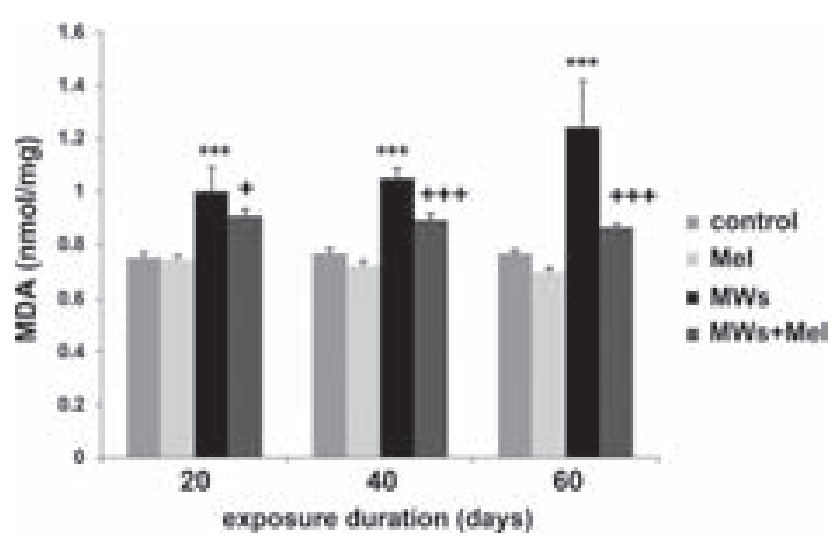

Figure 1. The effect of melatonin (Mel) on lipid peroxidation (MDA level) in the thymus of rats exposed to microwave radiation (MWs). ${ }^{* * *} p<0.001$ vs. control, ${ }^{+} p<0.05$ vs. MWs, ${ }^{++} p<0.001$ vs. MWs. 


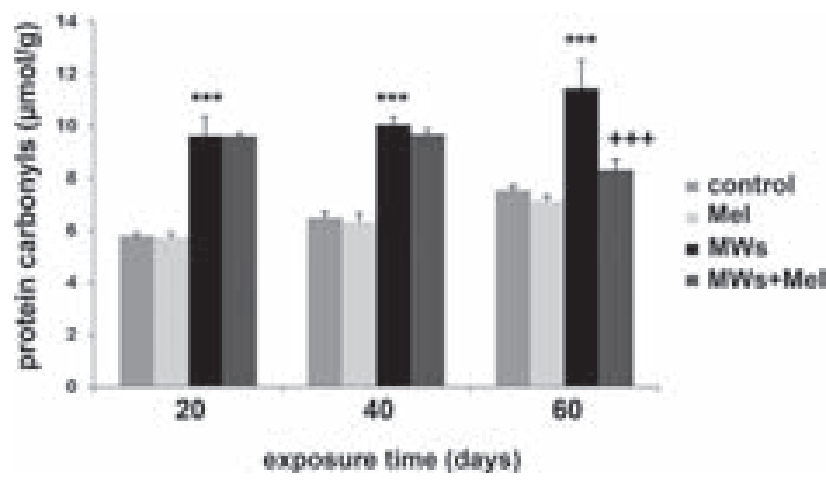

Figure 2. The effect of melatonin (Mel) on protein carbonyls in the thymus of rats exposed to microwave radiation (MWs); ${ }^{* * *} p<0.001$ vs. control and Mel, ${ }^{+++} p<0.001$ vs. MWs.

nificant dicrease in alkaline-DNase activity in the thymus tissue of MW exposed animals in experiments that lasted 20 days $(p<0.01), 40$ days $(p<0.001)$ and 60 days $(p<0.001)$, as shown in Fig. 5.

An increased acid-DNase activity was found in thymus tissue of rats exposed to MWs in comparison to controls after 20, 40 and 60 days of exposure $(p<0.001)$. Melatonin administration to irradiated animals (MWs + Mel group) led to statistically significant decrease in acid-DNase activity in thymus tissue after 20, 40 and 60 days $(p<0.001)$ of exposure (Fig. 6).

Melatonin effects on apoptosis in thymus tissue, determined by using Annexin V-FITC/PI detection kit, were estimated in thymocites obtained from animals that were irradiated for 20, 40 and 60 days. Both, apoptosis (total) and necrosis rate of thymocytes, obtained from animals that were irradiated 20 days, were significantly increased $(p<0.01)$, when compared to control. Melatonin administration caused a decrease in the apoptosis intensity (late and total, but not the early stage) and necrosis reduction $(p<0.05)$, in comparison to irradiated animals not treated with melatonin (Table 1). Apoptosis (late and total, but not the early stage) and necrosis rate of thymocytes obtained from animals that were irradiated 40 days, were also significantly increased ( $p<0.001 ; p<0.01 ; p<0.05$, respectively), when compared to control. Melatonin pretreatment caused significant decrease of the apoptosis intensity (total and late stage) and necrosis of thymocytes $(p<0.05)$, when compared to the animals that were exposed to radiation but were not treated with melatonin (Table 2). Finally, apoptosis (total and late stage, $p<0.001)$ and necrosis $(p<0.01)$ rate of thymocytes, obtained from animals that were irradiated 60 days, were significantly elevated, when compared to control. Melatonin administration caused decrease in the apoptosis intensity (total and late stage, $p<0.01$ ) in comparison to the animals that were exposed to radiation but did not received mela- tonin treatment but had no significant effect on the necrosis of thymocytes (Table 3).

As shown in Figure 8, proliferative capacity of thymocytes (triggered by Con A) was significantly reduced due to exposure to MWs (after 20, 40 and 60 days), when compared to control $(p<0.001)$. Melatonin administration led to significant increase in proliferative capacity in thymocytes obtained from animals that were irradiated 20 days, 40 days $(p<0.05)$ and 60 days $(p<0.01)$, in comparison to animals that were irradiated but did not received melatonin (Fig. 7).

\section{Discussion}

Biological effects of low-intensive MWs such as reactive oxygen species overproduction may change apoptosis and proliferation rates therefore causing disruption of the immune system (Quaglino et al. 2000).

\section{Microwave radiation and oxidative stress in thymus tissue}

Electromagnetic fields are found to affect chemical reactions in biological systems that involve free radicals as intermediates, and has been observed to increase the level of some types of free radicals (Balci et al. 2009). Although many in vitro and in vivo studies allready reported oxidative damage to different organs caused by exposure to MWs, only Aydin and Akar (2011) showed oxidative stress-induced injury regarding immune organs.

In the present study oxidative stress intensity was assessed trough lipid peroxidation and proteine oxidation indicators. During the radiation exposure, significant increase of the lipid peroxidation, quantified as MDA level in the thymus tissue, was noted after 20 days since the begining of the experiment (Fig. 1). These results are in accordance

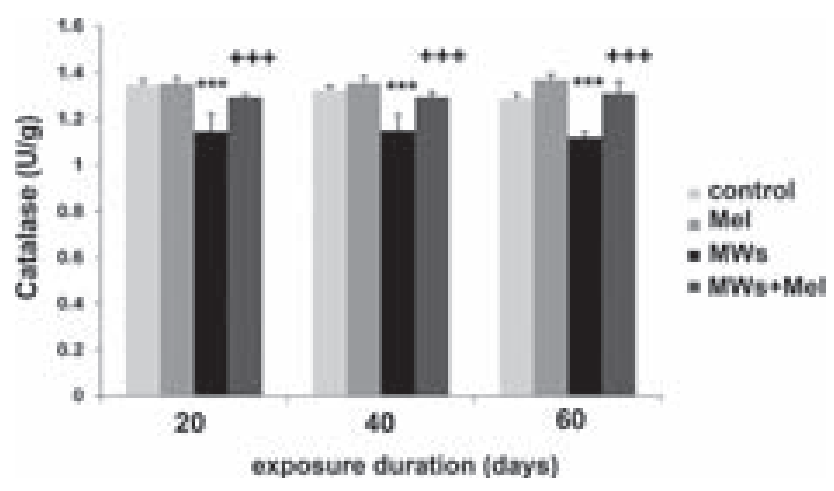

Figure 3. The effect of melatonin (Mel) on catalase in the thymus tissue of rats exposed to microwave radiation (MWs). ${ }^{* * *} p<0.001 \mathrm{vs}$. control and Mel, ${ }^{+++} p<0.001$ vs. MWs. 


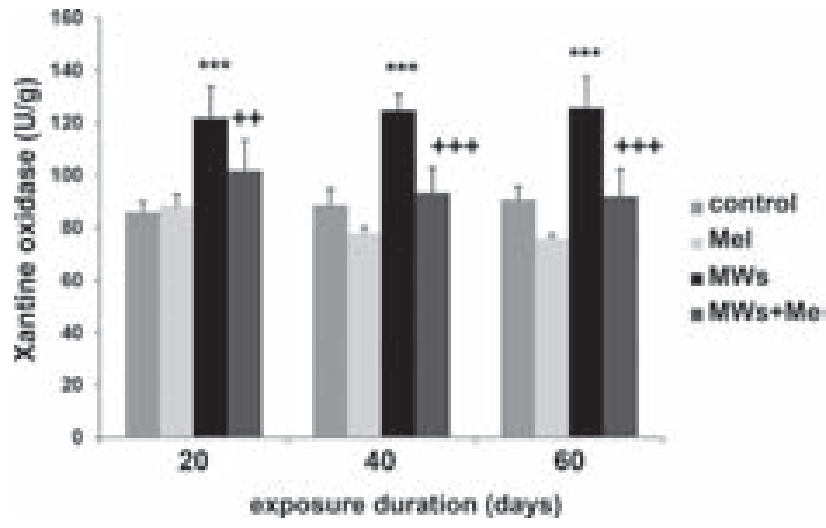

Figure 4. The effect of melatonin (Mel) on xanthine oxidase activity in the thymus tissue of rats exposed to microwave radiation (MWs). ${ }^{* * *} p<0.001$ vs. control and Mel, ${ }^{+++} p<0.001$ vs. MWs.

with those obtained by Aydin and Akar (2011) who reported significantly increased lipid peroxidation level in all lymphoid organs, including thymus. Increased MDA level, after exposure to $900 \mathrm{MHz} \mathrm{MWs}$, was previously shown in different tissues, such as brain of rats and guinea pigs (Ilhan et al. 2004; Köylü et al. 2006; Meral et al. 2007; Sokolovic et al. 2008), rat retina and rat renal tissue (Oktem et al. 2005; Ozguner et al. 2006).

Reactions between protein molecules and ROS often lead to modification of the certain amino acid residues forming carbonyl derivatives (Yan and Sohal 2002). Our previous study (Sokolovic et al. 2008) proved increased protein carbonyls content in rat brain after MW exposure. However, to the best knowledge of the autors there are no reported studies in the literature considering protein carbonyls content in the thymus tissue in response to MW exposure. The increase in protein carbonyls content in thymus tissue, as shown in the present study, occures after 20 days of exposure to MWs (Fig. 2), following the initial increase of ROS molecules and MDA.

CAT is considered to be an antioxidative enzyme. Its activity, similar to the other antioxidative enzymes, is sometimes diminished under the conditions of intensive oxidative stress (Reiter et al. 2000). Decreased CAT activity, due to $\mathrm{MW}$-induced injury, was previously reported in retina (Ozguner et al. 2006) and brain tissue (Sokolovic et al. 2008). Our results showed that exposure to MWs lead to significant decrease of CAT activity in thymus (Fig. 3), indicating the high degree of oxidative stress due to $\mathrm{H}_{2} \mathrm{O}_{2}$ increase. The decrease in CAT activity is probably caused by oxidative modification of enzyme molecules. Aydin and Akar (2011) also showed significant decrease in CAT activity in all lymphoid organs of rats suggesting that MWs cause impairment of antioxidant mechanisms, i.e. decrease in antioxidant enzyme levels, which can be interpreted as their indirect inhibition caused by binding to oxidative molecules.

Pro-oxidative XO activity is considered to be an important mechanism in pathogenesys of oxidative stress related diseases such as gout, cardiovascular diseases, diabetes and radiation damage (Desco et al. 2002; Biagi and Abate 2005; George and Struthers 2009). Previously, we showed increased XO activity in the brain tissue after prolonged exposure, i.e. 40 and 60 days (Sokolovic et al. 2008). However, the present study demonstrated that $\mathrm{XO}$ activity in thymus tissue increases after only 20 days of exposure to MWs (Fig. 4). Increased XO activity observed in the present study is probably partially responsible for increase of ROS.

Microwave radiation and oxidative stress - protective role of melatonin

In many studies melatonine has been found to protect against lipid peroxidation due to exposure to MWs. Melatonin has been considered as a potent anti-oxidant and efficient endogenous free radical scavenger. Melatonin molecules are capable of catching ${ }^{\circ} \mathrm{OH}$ and thus can be categorized as the first line of antioxidative defense (Sokolovic et al. 2008). Melatonin has its antioxidant effect in its first contact with the cell membrane, by attaching to the external surface of the phospholipid layer, reacting with radicals, and detoxifying them before the membrane does - protecting the membrane in such way (Col et al. 2010).

In the present study, premedication with melatonin has reduced lipid peroxidation level after 20 days of exposure to MWs. Similar effects were reported in studies by Ozguner et al. (2005b) and Köylü et al. (2006), which showed that melatonine treatment significantly decreases MDA level.

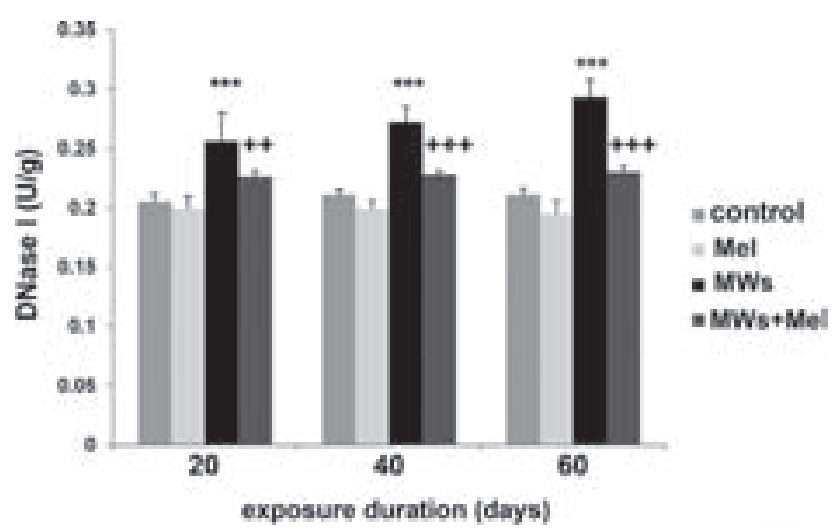

Figure 5. The effect of melatonin (Mel) on DNase I (alkaline) activity in the thymus tissue of rats exposed to microwave radiation (MWs). ${ }^{* * *} p<0.001$ vs. control and Mel, ${ }^{++} p<0.01$ vs. MWs, ${ }^{+++} p<0.001$ vs. MWs. 


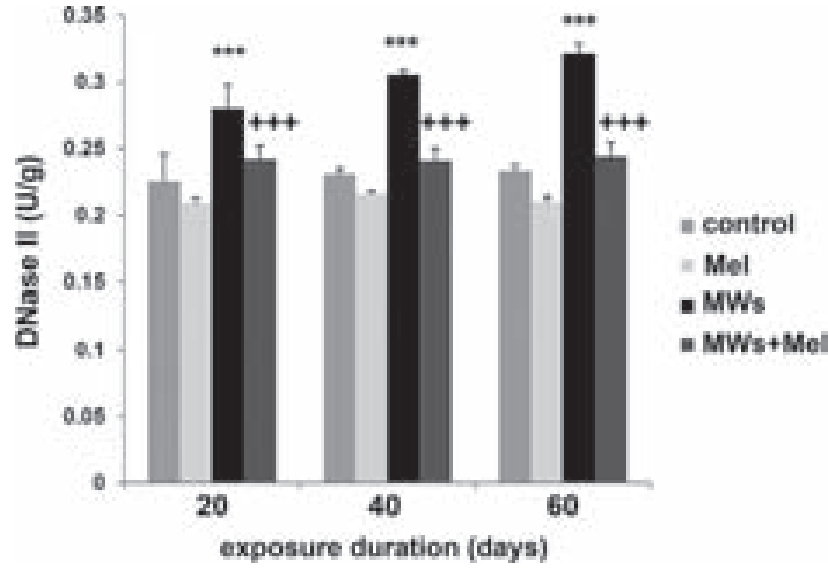

Fig. 6. The efect of melatonin (Mel) on DNase II (acid) activity in the thymus tissue of rats exposed to microwave radiation (MWs). ${ }^{* * *} p<0.001$ vs. control and Mel, ${ }^{+++} p<0.001$ vs. MWs.

Even if our previous study (Sokolovic et al. 2008) failed to prove the protective effect of melatonin on protein oxidation in the brain tissue of rats exposed to MWs, the present study showed significant decrease of protein carbonyls content after melatonin administration, suggesting the importance of melatonin administration in defence against oxidative stress induced injury in thymus tissue.

The decrease in CAT activity in thymus tissue after the exposure to MWs was attenuated when melatonin was administrated. This may be due to the general protective effect of melatonin on macromolecules including proteins (Reiter et al. 2000).
Melatonin administration has also significantly decreased $\mathrm{XO}$ activity after exposure to MWs, suggesting that antioxidative effects of melatonin are the result of both increased activity of antioxidative enzymes and decreased activity of pro-oxidative enzymes, such as XO.

\section{Microwave radiation effect on apoptosis of thymocytes and DNA fragmentation - protective role of melatonin}

The thymus gland is a central lymphoid organ in which bone marrow-derived $\mathrm{T}$ cell precursors undergo differentiation, eventually leading to migration of positively selected thymocytes to the peripheral lymphoid organs (Savino et al. 1998). Apoptosis is a key factor for negative selection of thymocytes and therefore crucial for normal immune system development (Sohn et al. 2007). Human lymphoid cells themselves are an important physiological source of melatonin that could be involved in regulation of the human immune system, possibly by acting as an intracrine, autocrine, and/or paracrine substance (Carrillo-Vico et al. 2004). Endogenous melatonin plays an essential role in the accurate response of human lymphocytes through the modulation of IL-2/IL-2 receptor system (CarrilloVico et al. 2005).Furthermore, melatonin protects human and murine CD4 [+] T cells from apoptosis by inhibiting CD95 ligand $\mathrm{mRNA}$ and protein upregulation in response to TCR/CD3 stimulation. This inhibition is a result of the interference with calmodulin/calcineurin activation of nuclear factor of activated t-cells (NFAT) that prevents the translocation of NFAT to the nucleus (Pedrosa et al. 2010).

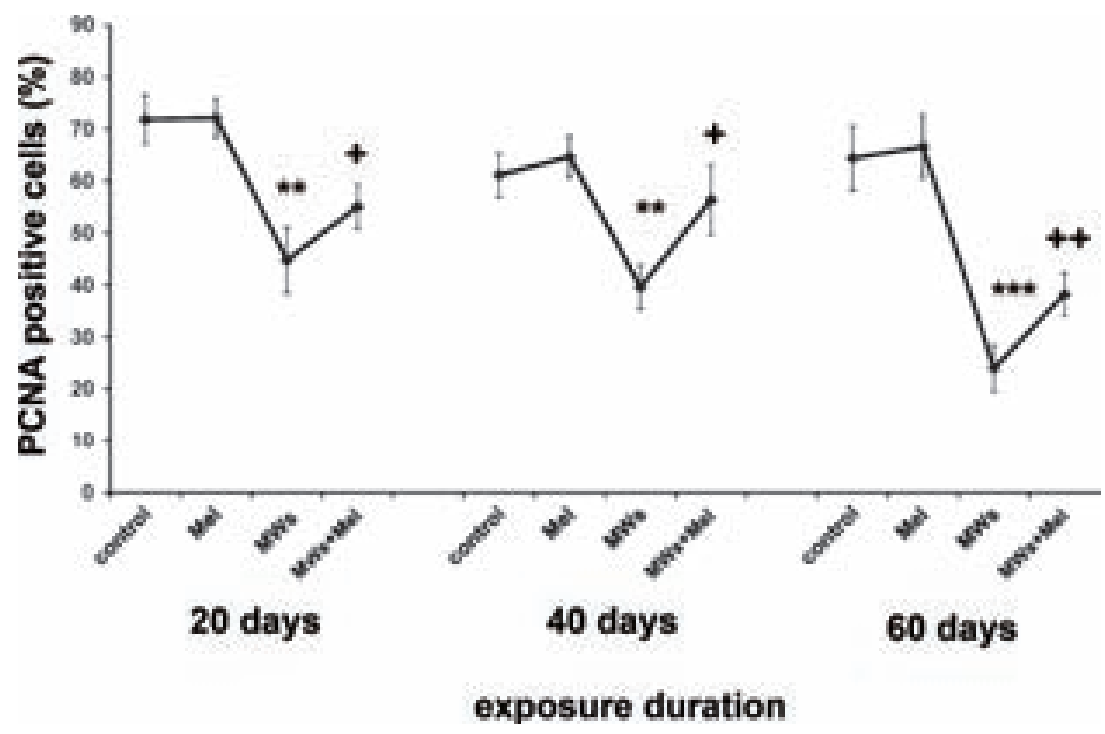

Fig. 7. The effect of melatonin (Mel) on proliferation of rat thymocytes after 20, 40 and 60 days of exposure to microwaves (MWs). PCNA, proliferating cell nuclear antigen; ${ }^{* *} p<0.001 v$ s. control and Mel, ${ }^{* *} p<0.01 v$ s. control and Mel, ${ }^{+} p<0.05 v s$. MWs, ${ }^{++} p<0.05 v s$. MWs. 
In the present study of apoptosis, we found significant increase in Annexien V-FITC and/ or Propidium iodide (PI) positive thymocytes in irradiated group. Moreover, the number of those cells was proportional to exposure duration. Therefore, we showed that MWs were able to induce apoptosis in rat thymocyte culture. In addition, an increase in alkaline and acid DNase activity was observed in thymus tissue after the exposure to MWs, suggesting that post apoptotic DNA degradation was as well intensified. These results correlate with the increased oxidative stress intensity in thymus tissue, indicating the participation of ROS in thymocyte apoptosis. Still, relatively high apoptosis rate of control cultures in the present study might have been caused by culture preparation process and removing thymocytes from their microenvironment. Our results are consistent with those obtained by Quaglino et al. (2000) who also reported that exposure to extremely low frequency MWs interferes with thimic cell death and causes alterations in the balance of cell death and other parameters such as mitoses which might interfere with the positive and negative selection of thymocytes.

Administration of melatonin reduced the number of Annexien V-FITC and/or PI positive thymocytes significantly. Furthermore, melatonin caused decrease in activity of alkaline and acid DNase in the thymus tissue of irradiated animals. Therefore, melatonin treatment significantly reduced apoptosis rate of irradiated thymocytes, what is in accordance with results of Sainz et al. (1995).

\section{Microwave radiation effect on thymocyte proliferation - the protective role of melatonin}

Proliferation of lymphocytes and their susceptibility to apoptosis are crucial factors for the immune system homeostasis maintenance. MW radiation effects on cell proliferation have been previously reported in the literature. Cleary et al. (1996) reported reduction in proliferation of $\mathrm{T}$ cells exposed to $\mathrm{MW}$ radiation.

In the present study, thymocyte proliferation in response to Con A was reduced as well after exposure to MWs. Reduced proliferation of thymocytes correlates with an increased oxidative stress intensity, therefore suggesting the role of ROS in thymus tissue damage. Moreover, melatonin treatment reversed those changes in proliferative capacity in a time-dependent manner. Described changes are probably mediated by the nuclear and/or membrane receptor mechanism and secretion of interleukins. It is well known that IL-2 and IL-6 cause T cell proliferation (Hope et al. 2000). Furthermore, melatonin enhances IL- 2 and IL- 6 production by human lymphocytic and monocytic cell lines via nuclear receptor-mediated mechanism (García-Mauriño et al. 2000). The expression of nuclear melatonin receptor seems to be sufficient for melatonin to activate cytokine production in human lymphocytic and monocytic cell lines (García-Mauriño et al. 2000).

According to our results, melatonin caused significant decrease in oxidative stress intensity by regulating lipid peroxidation, $\mathrm{CAT}$ and $\mathrm{XO}$ activity, and restored balance in antioxidative defence system. It also modulated processes of apoptosis and proliferation in thymus tissue exposed to MWs. Therefore, it acts as a protective factor for thymus exposed to microwave radiation.

Acknowledgements. This work was supported by the Ministry of Science and Technological development, Republic of Serbia (Project 43012).

\section{References}

Adey W. R. (1981): Tissue interactions with nonionizing electromagnetic fields. Physiol. Rev. 61, 435-514

Antolín I., Rodríguez C., Saínz R. M., Mayo J. C., Uría H., Kotler M. L., Rodríguez-Colunga M. J., Tolivia D., Menéndez-Peláez A. (1996): Neurohormone melatonin prevents cell damage: effect on gene expression for antioxidant enzymes. FASEB J. 10, 882-890

Aydin B., Akar A. (2011): Effects of a 900-MHz electromagnetic field on oxidative stress parameters in rat lymphoid organs, polymorphonuclear leukocytes and plasma. Arch. Med. Res. 42, 261-267 http://dx.doi.org/10.1016/j.arcmed.2011.06.001

Baan R., Grosse Y., Lauby-Secretan B., El Ghissassi F., Bouvard V., Benbrahim-Tallaa L., Guha N., Islami F., Galichet L., Straif K.; WHO International Agency for Research on Cancer Monograph Working Group (2011): Carcinogenicity of radiofrequency electromagnetic fields. Lancet Oncol. 12, 624-626 http://dx.doi.org/10.1016/S1470-2045(11)70147-4

Balci M., Namuslu M., Devrim E., Durak İ. (2009): Effects of computer monitor-emitted radiation on oxidant/antioxidant balance in cornea and lens from rats. Mol. Vis. 15, 2521-2525

Bartholeyns J., Peeters-Joris C., Reychler H., Baudhuin P. (1975): Hepatic nucleases. 1. Methods for the specific determination and characterization in rat liver. Eur. J. Biochem. 57, 205-211

http://dx.doi.org/10.1111/j.1432-1033.1975.tb02292.x

Baydas G., Canatan H., Turkoglu A. (2002): Comparative analysis of the protective effects of melatonin and vitamin E on streptozocin-induced diabetes mellitus. J. Pineal. Res. 32, 225-230 http://dx.doi.org/10.1034/j.1600-079X.2002.01856.x

Belyaev I. Y., Hillert L., Protopopova M., Tamm C., Malmgren L. O., Persson B. R., Selivanova G., Harms-Ringdahl M. (2005): 915 $\mathrm{MHz}$ microwaves and $50 \mathrm{~Hz}$ magnetic field affect chromatin conformation and 53BP1 foci in human lymphocytes from hypersensitive and healthy persons. Bioelectromagnetics 26, 173-184 http://dx.doi.org/10.1002/bem.20103

Belyaev I. Y. (2010): Dependence of non-thermal biological effects of microwaves on physical and biological variables: implications for reproducibility and safety standards. In: European Journal 
of Oncology - Library: Non-thermal effects and mechanisms of interaction between electromagnetic fields and living matter. An ICEMS Monograph, vol. 5 (Eds. L. Giuliani and M. Soffritti), pp. 201-231, National Institute for the Study and Control of Cancer and Environmental Diseases „Bernardino Ramazzini“, Bologna, Italy

Biagi P., Abate L. (2005): Heart failure, oxidative stress and allopurinol. Monaldi Arch. Chest Dis. 64, 33-37

Blank M., Goodman R. (2009): Electromagnetic fields stress living cells. Pathophysiology 16, 71-78 http://dx.doi.org/10.1016/j.pathophys.2009.01.006

Carrillo-Vico A., Calvo J. R., Abreu P., Lardone P. J., García-Mauriño S., Reiter R. J., Guerrero J. M. (2004): Evidence of melatonin synthesis by human lymphocytes and its physiological significance: possible role as intracrine, autocrine, and/or paracrine substance. FASEB J. 18, 537-539

Carrillo-Vico A., Lardone P. J., Fernández-Santos J. M., MartínLacave I., Calvo J. R., Karasek M., Guerrero J. M. (2005): Human lymphocyte-synthesized melatonin is involved in the regulation of the interleukin-2/interleukin-2 receptor system. J. Clin. Endocrinol. Metab. 90, 992-1000 http://dx.doi.org/10.1210/jc.2004-1429

Chiabrera A., Bianco B., Moggia E., Kaufman J. J. (2000): ZeemanStark modeling of the RF EMF interaction with ligand binding. Bioelectromagnetics 21, 312-324

http://dx.doi.org/10.1002/(SICI)1521-186X(200005)21:4<312:: AID-BEM7>3.0.CO;2-\#

Cleary S. F., Du Z., Cao G., Liu L. M., McCrady C. (1996): Effect of isothermal radiofrequency radiation on cytolytic T lymphocytes. FASEB J. 10, 913-919

Col C., Dinler K., Hasdemir O., Buyukasik O., Bugdayci G. (2010): Oxidative stress and lipid peroxidation products: effect of pinealectomy or exogenous melatonin injections on biomarkers of tissue damage during acute pancreatitis. Hepatobiliary Pancreat. Dis. Int. 9, 78-82

Cooke R., Laing S., Swerdlow A. J. (2010): A case-control study of risk of leukaemia in relation to mobile phone use. Br. J. Cancer 103, 1729-1735 http://dx.doi.org/10.1038/sj.bjc.6605948

Davanipour Z., Sobel E. (2009): Long-term exposure to magnetic fields and the risks of Alzheimer's disease and breast cancer: Further biological research. Pathophysiology 16, 149-156 http://dx.doi.org/10.1016/j.pathophys.2009.01.005

Desco M. C., Asensi M., Márquez R., Martínez-Valls J., Vento M., Pallardó F. V., Sastre J., Viña J. (2002): Xanthine oxidase is involved in free radical production in type 1 diabetes: protection by allopurinol. Diabetes 51, 1118-11124 http://dx.doi.org/10.2337/diabetes.51.4.1118

Drago F., Frisina M., Grech M., Nicolosi A., Micale V., Nicosia A., Medico M., Foti F. (2001): Dual effects of melatonin on barbiturate-induced narcosis in rats. Neurosci. Lett. 300, $176-178$ http://dx.doi.org/10.1016/S0304-3940(01)01578-6

Draper G., Vincent T., Kroll M. E., Swanson J. (2005): Childhood cancer in relation to distance from high voltage power lines in England and Wales: a case-control study. BMJ 330, 1290 http://dx.doi.org/10.1136/bmj.330.7503.1290
Friedman J., Kraus S., Hauptman Y., Schiff Y., Seger R. (2007): Mechanism of short-term ERK activation by electromagnetic fields at mobile phone frequencies. Biochem. J. 405, 559-568 http://dx.doi.org/10.1042/BJ20061653

García-Mauriño S., Pozo D., Calvo J. R., Guerrero J. M. (2000): Correlation between nuclear melatonin receptor expression and enhanced cytokine production in human lymphocytic and monocytic cell lines. J. Pineal Res. 29, 129-137 http://dx.doi.org/10.1034/j.1600-079X.2000.290301.x

George J., Struthers A. D. (2009): Role of urate, xanthine oxidase and the effects of allopurinol in vascular oxidative stress. Vasc. Health. Risk. Manag. 5, 265-272 http://dx.doi.org/10.2147/VHRM.S4265

Georgiou C. D. (2010): Oxidative stress-induced biological damage by low-level EMFs: mechanism of free radical pair electron spin- polarization and biochemical amplification In: European Journal of Oncology - Library: Non-thermal effects and mechanisms of interaction between electromagnetic fields and living matter. An ICEMS Monograph, vol. 5 (Eds. L. Giuliani and M. Soffritti), pp.77-113, National Institute for the Study and Control of Cancer and Environmental Diseases „Bernardino Ramazzini“, Bologna, Italy

Góth L. (1991): A simple method for determination of serum catalase activity and revision of reference range. Clin. Chim. Acta 196, 143-151 http://dx.doi.org/10.1016/0009-8981(91)90067-M

Hashimoto S. (1974): A new spectrophotometric assay method of xanthine oxidase in crude tissue homogenate. Anal. Biochem. 62, 426-435 http://dx.doi.org/10.1016/0003-2697(74)90175-4

Hope J. C., Campbell F., Hopkins S. J. (2000): Deficiency of IL-2 or IL-6 reduces lymphocyte proliferation, but only IL-6 deficiency decreases the contact hypersensitivity response. Eur. J. Immunol. 30, 197-203 http://dx.doi.org/10.1002/1521-4141(200001)30:1<197::AID-IMMU197>3.0.CO;2-9

Huang T. Q., Lee M. S., Oh E., Zhang B. T., Seo J. S., Park W. Y. (2008): Molecular responses of Jurkat T-cells to $1763 \mathrm{MHz}$ radiofrequency radiation. Int. J. Radiat. Biol. 84, 734-741 http://dx.doi.org/10.1080/09553000802317760

Ilhan A., Gurel A., Armutcu F., Kamisli S., Iraz M., Akyol O., Ozen S. (2004): Ginkgo biloba prevents mobile phone-induced oxidative stress in rat brain. Clin. Chim. Acta 340, 153-162 http://dx.doi.org/10.1016/j.cccn.2003.10.012

Irmak M. K., Fadillioğlu E., Güleç M., Erdoğan H., Yağmurca M., Akyol O. (2002): Effects of electromagnetic radiation from a cellular telephone on the oxidant and antioxidant levels in rabbits. Cell. Biochem. Funct. 20, 279-283 http://dx.doi.org/10.1002/cbf.976

Jou M. J., Peng T. I., Yu P. Z., Jou S. B., Reiter R. J., Chen J. Y., Wu H. Y., Chen C. C., Hsu L. F. (2007): Melatonin protects against common deletion of mitochondrial DNA-augmented mitochondrial oxidative stress and apoptosis. J. Pineal. Res. 43, 389-403 http://dx.doi.org/10.1111/j.1600-079X.2007.00490.x

Koopman G., Reutelingsperger C. P., Kuijten G. A., Keehnen R. M., Pals S. T., van Oers M. H. (1994): Annexin V for flow cytometric 
detection of phosphatidylserine expression on B cells undergoing apoptosis. Blood 84, 1415-1420

Köylü H., Mollaoglu H., Ozguner F., Naziroglu M., Delibas N. (2006:) Melatonin modulates $900 \mathrm{Mhz}$ microwave-induced lipid peroxidation changes in rat brain. Toxicol. Ind. Health. 22, 211-216 http://dx.doi.org/10.1191/0748233706th263oa

Kühn U., Lempertz U., Knop J., Becker D. (1995): A new method for phenotyping proliferating cell nuclear antigen positive cells using flow cytometry: implications for analysis of the immune response in vivo. J. Immunol. Methods 179, 215-222 http://dx.doi.org/10.1016/0022-1759(94)00287-7

Levine R. L., Williams J. A., Stadtman E. R., Shacter E. (1994): Carbonyl assays for determination of oxidatively modified proteins. Methods Enzymol. 233, 346-357 http://dx.doi.org/10.1016/S0076-6879(94)33040-9

Lowenthal R. M., Tuck D. M., Bray I. C. (2007): Residential exposure to electric power transmission lines and risk of lymphoproliferative and myeloproliferative disorders: a case-control study. Intern. Med. J. 37, 614-619 http://dx.doi.org/10.1111/j.1445-5994.2007.01389.x

Lowry O. H., Rosenbrough N. J., Farr A. L., Randall R. J. (1951): Protein measurement with the Folin phenol reagent. J. Biol. Chem. 193, 265-275

Matronchik A. I., Alipov E. D., Beliaev I. I. (1996): [A model of phase modulation of high frequency nucleoid oscillations in reactions of E. coli cells to weak static and low-frequency magnetic fields]. Biofizika 41, 642-649

Matronchik A. Y., Belyaev I. Y. (2008): Mechanism for combined action of microwaves and static magnetic field: slow non uniform rotation of charged nucleoid. Electromagn. Biol. Med. 27, 340-354 http://dx.doi.org/10.1080/15368370802493313

Matsui N., Nitta T., Takahama Y. (2011): Development of the thymus and immune system. Brain. Nerve 63, 679-684

Meral I., Mert H., Mert N., Deger Y., Yoruk I., Yetkin A., Keskin S. (2007): Effects of 900-MHz electromagnetic field emitted from cellular phone on brain oxidative stress and some vitamin levels of guinea pigs. Brain Res. 1169, 120-124 http://dx.doi.org/10.1016/j.brainres.2007.07.015

Merzenich H., Schmiedel S., Bennack S., Brüggemeyer H., Philipp J., Blettner M., Schüz J. (2008): Childhood leukemia in relation to radio frequency electromagnetic fields in the vicinity of TV and radio broadcast transmitters. Am. J. Epidemiol. 168, $1169-1178$ http://dx.doi.org/10.1093/aje/kwn230

Mukai F., Goldstein B. (1976): Mutagenicity of malonaldehyde, a decomposition product of peroxidized polyunsaturated fatty acids. Science 191, 868-869 http://dx.doi.org/10.1126/science.766187

Myung S. K., Ju W., McDonnell D. D., Lee Y. J., Kazinets G., Cheng C., Moskowitz J. M. (2009): Mobile phone use and risk of tumors: a meta-analysis. J. Clin. Oncol. 27, 5565-5572 http://dx.doi.org/10.1200/JCO.2008.21.6366

Ohkawa H., Ohishi N., Yagi K. (1979): Assay for lipid peroxides in animal tissues by thiobarbituric acid reaction. Anal. Biochem. 95, 351-358 http://dx.doi.org/10.1016/0003-2697(79)90738-3
Oktem F., Ozguner F., Mollaoglu H., Koyu A., Uz E. (2005): Oxidative damage in the kidney induced by $900-\mathrm{MHz}$-emitted mobile phone: protection by melatonin. Arch. Med. Res. 36, 350-355 http://dx.doi.org/10.1016/j.arcmed.2005.03.021

Ozguner F., Altinbas A., Ozaydin M., Dogan A., Vural H., Kisioglu A. N., Cesur G., Yildirim N. G. (2005a): Mobile phone-induced myocardial oxidative stress: protection by a novel antioxidant agent caffeic acid phenethyl ester. Toxicol. Ind. Health. 21, 223-230 http://dx.doi.org/10.1191/0748233705th228oa

Ozguner F., Oktem F., Armagan A., Yilmaz R., Koyu A., Demirel R., Vural H., Uz E. (2005b): Comparative analysis of the protective effects of melatonin and caffeic acid phenethyl ester (CAPE) on mobile phone-induced renal impairment in rat. Mol. Cell. Biochem. 276, 31-37 http://dx.doi.org/10.1007/s11010-005-2734-8

Ozguner F., Bardak Y.,Comlekci S. (2006): Protective effects of melatonin and caffeic acid phenethyl ester against retinal oxidative stress in long-term use of mobile phone: a comparative study. Mol. Cell. Biochem. 282, 83-88 http://dx.doi.org/10.1007/s11010-006-1267-0

Panagopoulos D. J., Karabarbounis A., Margaritis L. H. (2002): Mechanism for action of electromagnetic fields on cells. Biochem. Biophys. Res. Commun. 298, 95-102 http://dx.doi.org/10.1016/S0006-291X(02)02393-8

Pedrosa A. M., Weinlich R., Mognol G. P., Robbs B. K., Viola J. P., Campa A., Amarante-Mendes G. P. (2010): Melatonin protects CD4+ T cells from activation-induced cell death by blocking NFAT-mediated CD95 ligand upregulation. J. Immunol. 184, 3487-3494

http://dx.doi.org/10.4049/jimmunol.0902961

Perentos N., Iskra S., McKenzie R. J., Cosi I. (2008): Simulation of pulsed ELF magnetic fields generated by GSM mobile phone handsets for human electromagnetic bioeffects research. Australas. Phys. Eng. Sci. Med. 31, 235-242 http://dx.doi.org/10.1007/BF03179350

Poeggeler B., Reiter R. J., Tan D. X., Chen L. D., Manchester L. C. (1993): Melatonin, hydroxyl radical-mediated oxidative damage, and aging: a hypothesis. J. Pineal. Res. 14, 151-168 http://dx.doi.org/10.1111/j.1600-079X.1993.tb00498.x

Pozo D., Delgado M., Fernandez-Santos J. M., Calvo J. R., Gomariz R. P., Martin-Lacave I., Ortiz G. G., Guerrero J. M. (1997): Expression of the Mella-melatonin receptor mRNA in T and $B$ subsets of lymphocytes from rat thymus and spleen. FASEB J. 11, 466-473

Quaglino D., Capri M., Bergamini G., Euclidi E., Zecca L., Franceschi C., Ronchetti I. P. (1998): Age-dependent remodeling of rat thymus. Morphological and cytofluorimetric analysis from birth up to one year of age. Eur. J. Cell. Biol. 76, 156-166 http://dx.doi.org/10.1016/S0171-9335(98)80029-0

Quaglino D., Capri M., Ronchetti I. P. (2000): Modulation of cell death in the rat thymus. Light and electron microscopic investigations. Ann. N.Y. Acad. Sci. 926, 79-82 http://dx.doi.org/10.1111/j.1749-6632.2000.tb05600.x

Reiter R. J., Tan D. X., Osuna C., Gitto E. (2000): Actions of melatonin in the reduction of oxidative stress. A review. J. Biomed. Sci. 7, 444-458 
http://dx.doi.org/10.1007/BF02253360

Sainz R. M., Mayo J. C., Rodriguez C., Tan D. X., Lopez-Burillo S., Reiter R. J. (2003): Melatonin and cell death: differential actions on apoptosis in normal and cancer cells. Cell. Mol. Life. Sci. 60, 1407-1426 http://dx.doi.org/10.1007/s00018-003-2319-1

Sainz R. M., Mayo J. C., Uría H., Kotler M., Antolín I., Rodriguez C., Menendez-Pelaez A. (1995): The pineal neurohormone melatonin prevents in vivo and in vitro apoptosis in thymocytes. J. Pineal. Res. 19, 178-188 http://dx.doi.org/10.1111/j.1600-079X.1995.tb00187.x

Savino W., Dardenne M. (1998): Neuroendocrine control of the thymus. Endocr. Rev. 21, 412-443 http://dx.doi.org/10.1210/er.21.4.412

Smirnov A. N. (2001): Nuclear melatonin receptors. Biochemistry (Mosc) 66, 19-26 http://dx.doi.org/10.1023/A:1002821427018

Sohn S. J., Thompson J., Winoto A. (2007): Apoptosis during negative selection of autoreactive thymocytes. Curr. Opin. Immunol. 19, 510-515 http://dx.doi.org/10.1016/j.coi.2007.06.001

Sokolovic D., Djindjic B., Nikolic J., Bjelakovic G., Pavlovic D., Kocic G., Krstic D., Cvetkovic T., Pavlovic V. (2008): Melatonin reduces oxidative stress induced by chronic exposure of microwave radiation from mobile phones in rat brain. J. Radiat. Res. (Tokyo) 49, 579-586 http://dx.doi.org/10.1269/jrr.07077

St-Pierre L. S., Mazzuchin A., Persinger M. A. (2008): Altered blood chemistry and hippocampal histomorphology in adult rats following prenatal exposure to physiologically-patterned, weak (50-500 nanoTesla range) magnetic fields. Int. J. Radiat. Biol. 84, 325-335

http://dx.doi.org/10.1080/09553000801953300

Vermes I., Haanen C., Steffens-Nakken H., Reutelingsperger C. (1995): A novel assay for apoptosis. Flow cytometric detection of phosphatidylserine expression on early apoptotic cells using fluorescein labelled Annexin V. J. Immunol. Methods 184, 39-51

http://dx.doi.org/10.1016/0022-1759(95)00072-I

von Gall C., Stehle J. H., Weaver D. R. (2002): Mammalian melatonin receptors: molecular biology and signal transduction. Cell. Tissue. Res. 309, 151-162 http://dx.doi.org/10.1007/s00441-002-0581-4

Yan L. J., Sohal R. S. (2002): Analysis of oxidative modification of proteins. Curr. Protoc. Cell. Biol. Chapter 7: Unit17.9

Yan M., Shen J., Person M. D., Kuang X., Lynn W. S., Atlas D., Wong P. K. Y. (2008): Endoplasmic reticulum stress and unfolded protein response in Atm-deficient thymocytes and thymic lymphoma cells are attributable to oxidative stress. Neoplasia 10, $160-167$ http://dx.doi.org/10.1593/neo.07935

Zotti-Martelli L., Peccatori M., Scarpato R., Migliore L. (2000): Induction of micronuclei in human lymphocytes exposed in vitro to microwave radiation. Mutat. Res. 472, 51-58 http://dx.doi.org/10.1016/S1383-5718(00)00112-1

Received: June 27, 2012

Final version accepted: October 2, 2012 